\title{
Mitochondrial Biogenesis in Response to Chromium (VI) Toxicity in Human Liver Cells
}

\author{
Xiali Zhong ${ }^{1}$, Rita de Cássia da Silveira e Sá ${ }^{2}$ and Caigao Zhong ${ }^{1, *}$ \\ 1 Department of Health Toxicology, School of Public Health, Central South University, Changsha 410008, \\ China; xzhong16@jhu.edu \\ 2 Department of Physiology and Pathology, Health Sciences Center, Federal University of Paraíba, \\ João Pessoa 58059-900, Brazil; ritacassia.sa@bol.com.br \\ * Correspondence: zcg54@csu.edu.cn; Tel.: +86-731-8480-5461
}

Received: 30 June 2017; Accepted: 25 August 2017; Published: 14 September 2017

\begin{abstract}
Hexavalent chromium $(\mathrm{Cr}(\mathrm{VI}))$ is a ubiquitous environmental pollutant, which poses a threat to human public health. Recent studies have shown that mitochondrial biogenesis can be activated by inflammatory and oxidative stress. However, whether mitochondrial biogenesis is involved in $\mathrm{Cr}(\mathrm{VI})$-induced hepatotoxicity is unclear. Here, we demonstrated the induction of inflammatory response and oxidative stress, as indicated by upregulation of inflammatory factors and reactive oxygen species (ROS). Subsequently, we demonstrated that mitochondrial biogenesis, comprising the mitochondrial DNA copy number and mitochondrial mass, was significantly increased in HepG2 cells exposed to low concentrations of $\mathrm{Cr}(\mathrm{VI})$. Expression of genes related to mitochondrial function complex I and complex $\mathrm{V}$ was upregulated at low concentrations of $\mathrm{Cr}(\mathrm{VI})$. mRNA levels of antioxidant enzymes, including superoxide dismutase 1 and 2 (SOD1 and $S O D 2$, respectively), kech like ECH associate protein 1 (KEAP1) and nuclear respiratory factor 2 (NRF-2), were also upregulated. Consistent with the above results, mRNA and protein levels of key transcriptional regulators of mitochondrial biogenesis such as the peroxisome-proliferator-activated receptor $\gamma$ coactivator- $1 \alpha$ (PGC-1 $\alpha$ ), NRF-1 and mitochondrial transcription factor A (TFAM) were increased by low concentrations of $\mathrm{Cr}(\mathrm{VI})$ in HepG2 cells. Moreover, we found that PGC-1 $\alpha$ and NRF-1 tended to translocate into the nucleus. The expression of genes potentially involved in mitochondrial biogenesis pathways, including mRNA level of silent information regulator-1 (SIRT1), forkhead box class-O (FOXO1), threonine kinase 1 (AKT1), and cAMP response element-binding protein (CREB1), was also upregulated. In contrast, mitochondrial biogenesis was inhibited and the expression of its regulatory factors and antioxidants was downregulated at high and cytotoxic concentrations of $\mathrm{Cr}(\mathrm{VI})$ in HepG2 cells. It is believed that pretreatment with $\alpha$-tocopherol could be acting against the mitochondrial biogenesis imbalance induced by $\mathrm{Cr}(\mathrm{VI})$. In conclusion, our study suggests that the homeostasis of mitochondrial biogenesis may be an important cellular compensatory mechanism against $\mathrm{Cr}(\mathrm{VI})$-induced toxicity and a promising detoxification target.
\end{abstract}

Keywords: mitochondrial biogenesis; hexavalent chromium; mitochondrial DNA; HepG 2 cells

\section{Introduction}

Hexavalent chromium $(\mathrm{Cr}(\mathrm{VI}))$ is widely distributed in the environment and commonly used in industries. It has been demonstrated that $\mathrm{Cr}(\mathrm{VI})$ can cause lung cancer through occupational exposure to contaminated air [1]. However, the general population is exposed to $\mathrm{Cr}(\mathrm{VI})$ through consumption of contaminated drinking water, which results in severe public health issues [2]. The United State National Toxicology Program conducted short-term and long-term toxicity and carcinogenicity studies on $\mathrm{Cr}(\mathrm{VI})$ in drinking water, and reported that $\mathrm{Cr}(\mathrm{VI})$ caused oral and small intestine cancer, and liver injury in rodents [3]. Human oral exposure to $\mathrm{Cr}(\mathrm{VI})$ has been shown to produce hepatotoxicity and 
provided evidence that $\mathrm{Cr}(\mathrm{VI})$ accumulation occurs mostly in the liver-The largest detoxification organ by oral exposure route [4,5]. Moreover, $\mathrm{Cr}(\mathrm{VI})$ may cause primary liver cancer and increase the risk of deterioration of cancer patients [6,7]. The mechanism of $\mathrm{Cr}(\mathrm{VI})$-induced hepatotoxicity is still not fully understood. Previous studies indicated that $\mathrm{Cr}(\mathrm{VI})$ could cause liver damage through the formation of DNA double-strand breaks and Cr-DNA adducts in the nuclear DNA [4]. It has also been shown that mitochondrial dysfunction could be caused by $\mathrm{Cr}(\mathrm{VI})$ exposure: $\mathrm{Cr}(\mathrm{VI})$ could reduce mitochondrial DNA (mtDNA) copy number and inhibit mitochondria electron transport chain complex I, resulting in perturbation of mitochondrial respiration and redox homeostasis [8,9]. These reports indicate that mitochondrion is one of the most sensitive targets of $\mathrm{Cr}(\mathrm{VI})$ toxicity.

Mitochondrial biogenesis is among the self-repairing and compensatory mechanisms that can be activated by cellular stress and inflammatory response or in response to environmental stimuli to maintain energetic and redox homeostasis [10]. Cell respiratory defects and reactive oxygen species (ROS) production can activate mitochondrial biogenesis as an adaptive strategy to respond to diverse mitochondrial disturbances [11]. One main regulator of mitochondrial biogenesis is the peroxisome-proliferator-activated receptor $\gamma$ coactivator- $1 \alpha$ (PGC-1 $\alpha$ ) [12], which is modulated by the binding of cAMP response element-binding protein (CREB), the activating transcription factor (ATF2), and the forkhead box class-O (FOXO1) [13]. PGC-1 $\alpha$ interacts with CREB and several other transcriptional factors to control other downstream factors, including nuclear respiratory factor 1 (NRF-1) and NRF-2, and to regulate the subsequent transcription of multiple genes involved in mitochondrial biogenesis and energy metabolism [14]. Mitochondrial biogenesis takes place as part of the normal cell proliferation process to maintain the increasing cell mass in general conditions. When it encounters cellular stress, mitochondrial biogenesis is extended to sustain ATP supply and to keep up with the increasing energy demand [15]. PGC-1 $\alpha$, NRF-1 and NRF-2 are primarily localized in the cytoplasm under general physiological conditions. However, in response to stress, nuclear genes related to mitochondrial biogenesis translocate to the nucleus and bind to downstream transcription factors to process their transcriptional activity. Consequently, transcription of genes related to mitochondrial biogenesis is initiated [16,17], and includes an increase of mitochondrial transcription factor A (TFAM) [18], which functions to replicate and transcribe mtDNA, promoting mitochondrial biogenesis, and possibly packing and repairing of mtDNA to prevent damage [19].

It has been well established that $\mathrm{Cr}(\mathrm{VI})$ can disrupt mitochondrial function in liver cells. However, whether mitochondrial biogenesis is involved in $\mathrm{Cr}(\mathrm{VI})$-induced hepatotoxicity is unclear. In the present study, we used Human Hepatocellular Carcinoma cells (HepG2) as a model to investigate the effect of $\mathrm{Cr}(\mathrm{VI})$ on mitochondrial biogenesis.

\section{Results}

\subsection{Cr(VI) Induces Cytotoxicity and Cell Death in HepG2 Cells}

Cytotoxicity experiments were performed to estimate sub-cytotoxic concentrations of $\mathrm{Cr}(\mathrm{VI})$ by determining cell viability and lactate dehydrogenase (LDH) release. After exposure to $\mathrm{Cr}(\mathrm{VI})$ for $24 \mathrm{~h}$, HepG2 cells did not exhibit any change in cell viability at concentrations lower than $10 \mu \mathrm{M}$. However, the cell viability was significantly decreased in a concentration-dependent manner over a range of $\mathrm{Cr}(\mathrm{VI})$ concentrations between 20 and $80 \mu \mathrm{M}$. In the LDH release assay, $\mathrm{Cr}(\mathrm{VI})$ significantly and concentration-dependently increased LDH release. Apoptotic cell death was confirmed by increased activation of caspases-3/7 and caspase-8 in HepG2 cells exposed to $\mathrm{Cr}(\mathrm{VI})$ at different concentrations. Apoptotic cells with activated caspase-3/7 exhibited bright green nuclei, whose intensity increased with increasing concentrations of $\mathrm{Cr}(\mathrm{VI})$ (Figure 1D). The mRNA levels of caspase-3 and caspase- 8 were consistent with the caspase- $3 / 7$ staining change. Based on the results above, it is believed that $\mathrm{Cr}(\mathrm{VI})$ induced cytotoxicity and cell death in HepG2 cells, and that these cells could tolerate $\mathrm{Cr}(\mathrm{VI})$-induced insult at lower range concentrations up to $10 \mu \mathrm{M}$. 

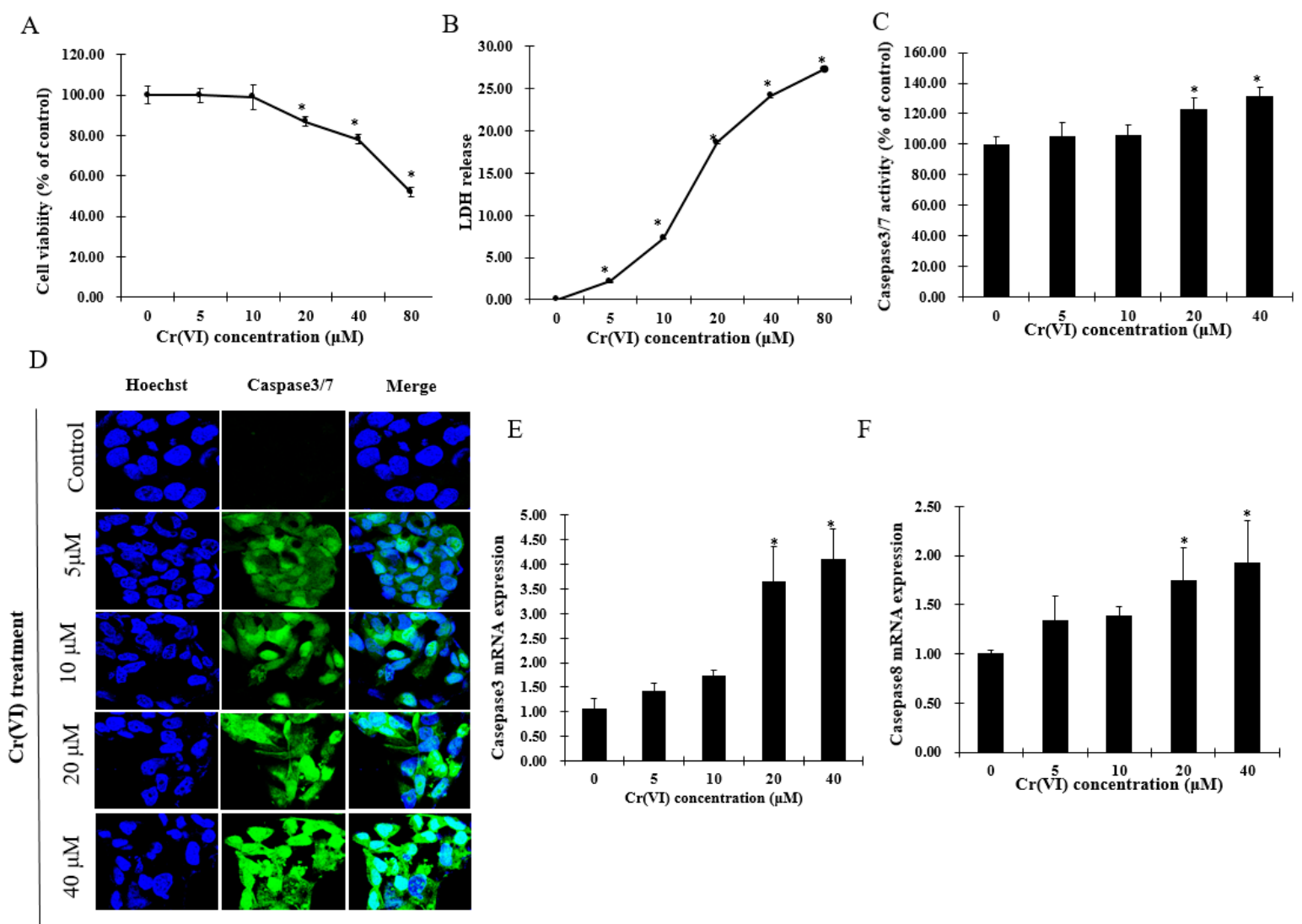

$\mathrm{F}$

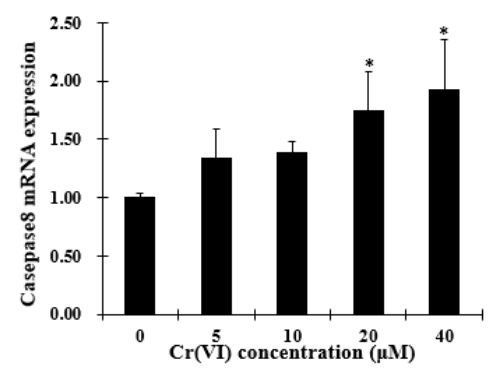

Figure 1. Hexavalent chromium ( $\mathrm{Cr}(\mathrm{VI}))$ induces cytotoxicity and cell death of HepG2 cells. (A) Cell viability of HepG2 cells exposed to $\mathrm{Cr}(\mathrm{VI})$ for $24 \mathrm{~h}$ was performed by resazurin reduction assays; (B) lactate dehydrogenase (LDH) release of HepG2 cells exposed to $\mathrm{Cr}(\mathrm{VI})$ for $24 \mathrm{~h}$ was evaluated with LDH assays; (C) percentage of caspase-3/7 positively stained cells were normalized with the total nuclei count by using Image-J software; (D) caspase-3/7 activity of HepG2 cells exposed to Cr(VI) for $24 \mathrm{~h}$. Green signals located in the nuclei indicate caspase-3/7 activation. Nuclei were stained with Hoechst 33342. Images were captured with confocal microscope (Zeiss, Germany), scale bar $10 \mu \mathrm{m}$; (E,F) mRNA expression level of caspase- 3 and caspase- 8 was detected by real-time qPCR. Data are presented as mean $\pm \mathrm{SME}$ of the values obtained in three independent experiments, each using triplicate cultures. After outlier analysis, the number of values used in the calculation of the corresponding mean varied from six to nine. ${ }^{*}$ Compared with control; ${ }^{*} p<0.05$.

\subsection{The Effect of $\mathrm{Cr}(V I)$ on the mRNA Level of Inflammatory Cytokines and Redox Reaction in HepG2 Cells}

The mRNA levels of tumor necrosis factor (TNF) and interleukin 1- $\beta$ (IL-1 $\beta$ ) were increased in a concentration-dependent manner (Figure 2A,B). As pro-inflammatory cytokines are driven by toll-like receptor (TLR)-mediated signals, TLR2 and TLR4 expression was examined by real-time qPCR, which showed that both TLR2 and TLR4 mRNA levels were significantly upregulated (Figure 2A). Cells stained with CellROX ${ }^{\circledR}$ Green and analyzed by a plate reader revealed that $\mathrm{Cr}(\mathrm{VI})$ increased ROS levels in a concentration-dependent manner (Figure 2B). However, the antioxidant enzymes superoxide dismutase (SOD1, SOD2), glutathione S-transferase O 1 (GSOT1), nuclear respiratory factor 2 (NRF-2) and kelch like ECH associate protein 1 (KEAP1) mRNA levels were upregulated at $\mathrm{Cr}(\mathrm{VI})$ concentrations up to $10 \mu \mathrm{M}$, which tended to decrease at $20 \mu \mathrm{M}$ (Figure 2C,D). 
A

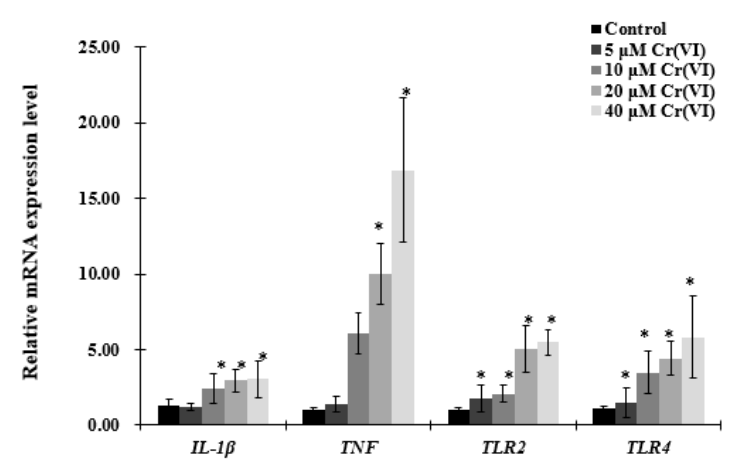

C

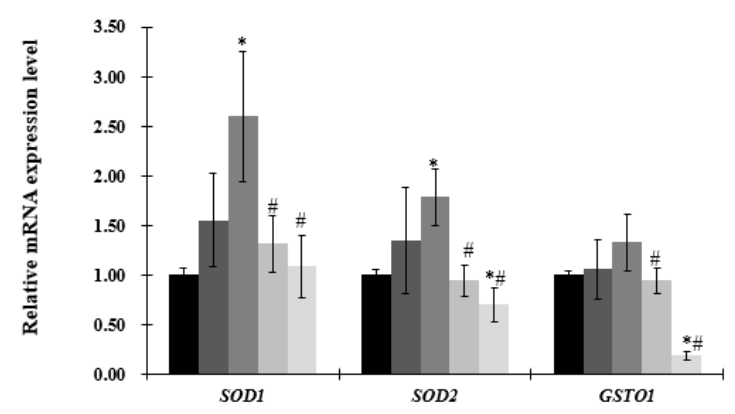

B

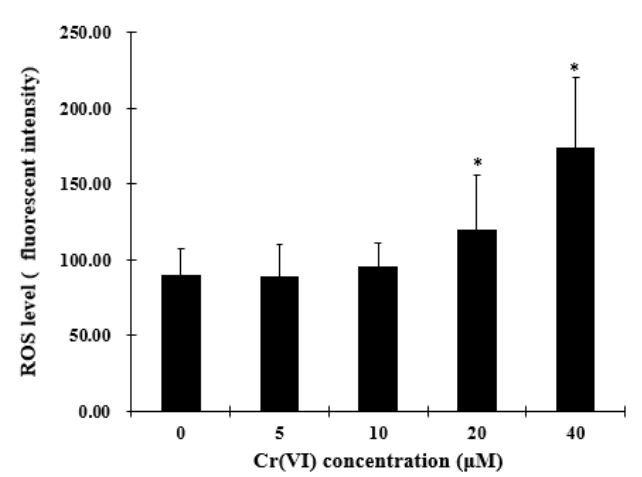

$\mathrm{D}$

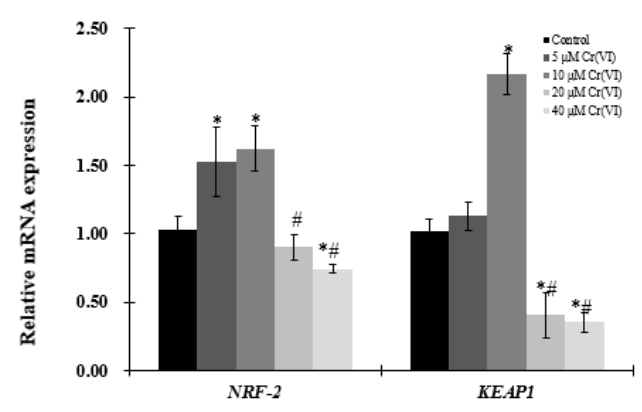

Figure 2. Effects of $\mathrm{Cr}(\mathrm{VI})$ on inflammatory cytokines and antioxidant enzymes in HepG2 cells. $(\mathbf{A}, \mathbf{C}, \mathbf{D})$ mRNA expression levels of genes were detected by real-time qPCR; and (B) reactive oxygen species (ROS) intensity was detected by using CellROX ${ }^{\circledR}$ Green reagent. Data are presented as means \pm SME of the values obtained in three independent experiments, each using triplicate cultures. After outlier analysis, the number of values used in the calculation of the corresponding mean varied from six to nine. * Compared with control, ${ }^{*} p<0.05$; \# compared with $2 \mu \mathrm{M}$ of $\mathrm{Cr}(\mathrm{VI})$ treatment group, $\# p<0.05$. Abbreviations: glutathione S-transferase $\Omega 1$, GSOT1; interleukin 1- $\beta$, IL-1 $\beta$; kelch like $\mathrm{ECH}$ associate protein 1, KEAP1; nuclear respiratory factor $2, N R F-2$; reactive oxygen species, ROS; superoxide dismutase, $S O D$; tumor necrosis factor, TNF; toll-like receptor $2 / 4, T L R 2 / 4$.

\subsection{Exposure to Low Concentrations of Cr(VI) Induces Adaptive Upregulation of Mitochondrial Biogenesis}

To evaluate mitochondrial biogenesis, mtDNA copy number and mitochondrial mass were examined. Increase in mtDNA copy number and mitochondrial mass was observed in HepG2 cells exposed to up to $10 \mu \mathrm{M}$ of $\mathrm{Cr}(\mathrm{VI})$, followed by a decrease at $20 \mu \mathrm{M}$ (Figure 3A,B). Mitochondrial function was assessed by complex I (NADH: ubiquinone oxidoreductase subunit A1 (NDUFA1) or NADH: ubiquinone oxidoreductase subunit B1 (NDUFB1)) and complex V (ATP synthase, $\mathrm{H}+$ transporting, mitochondrial Fo complex subunit F6 (ATP5J) or ATP synthase, H+ transporting, mitochondrial F1 complex, O subunit (ATP5O)). The mRNA level of NDUFA1, but not of NDUFB1, was significantly increased at concentrations up to $10 \mu \mathrm{M}$ of $\mathrm{Cr}(\mathrm{VI})$, while the highest concentration produced statistically significant decrease of both NDUFA1 and NDUFB1. ATP5J and ATP5O mRNA expression was upregulated at concentrations up to $10 \mu \mathrm{M}$ of $\mathrm{Cr}(\mathrm{VI})$, but decreased at $20 \mu \mathrm{M}$ (Figure 3D). 
A

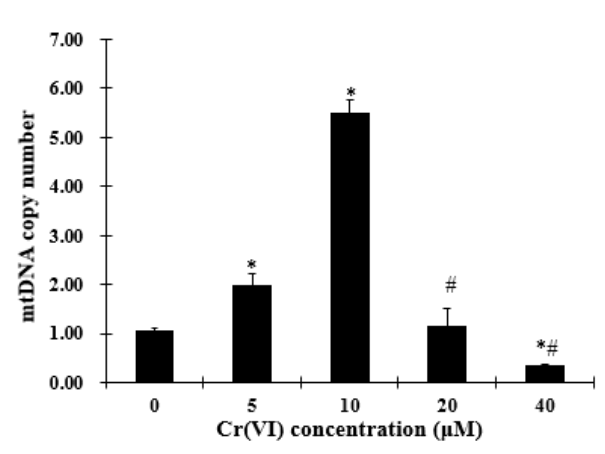

$\mathrm{C}$

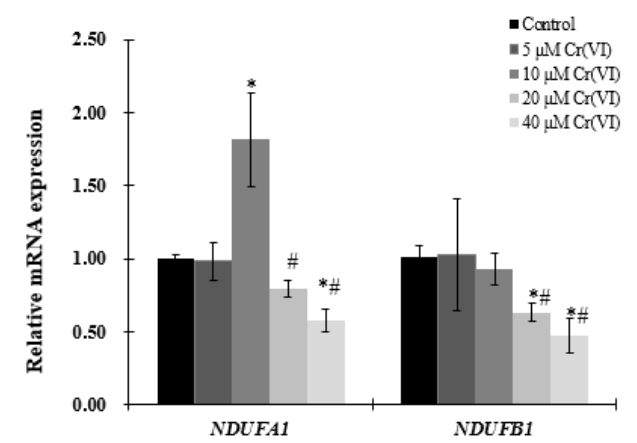

B

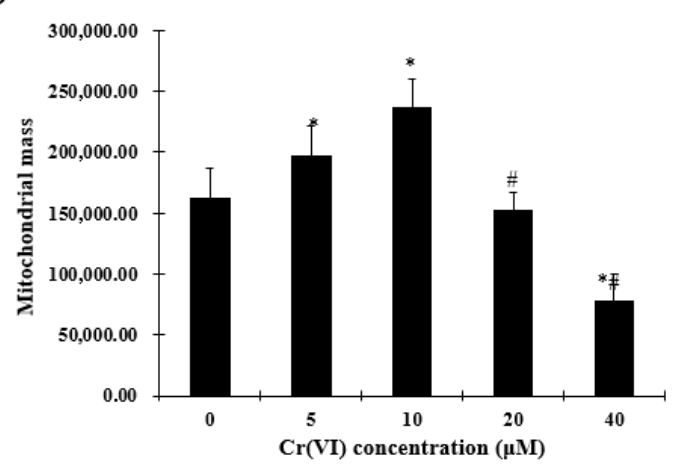

$\mathrm{D}$

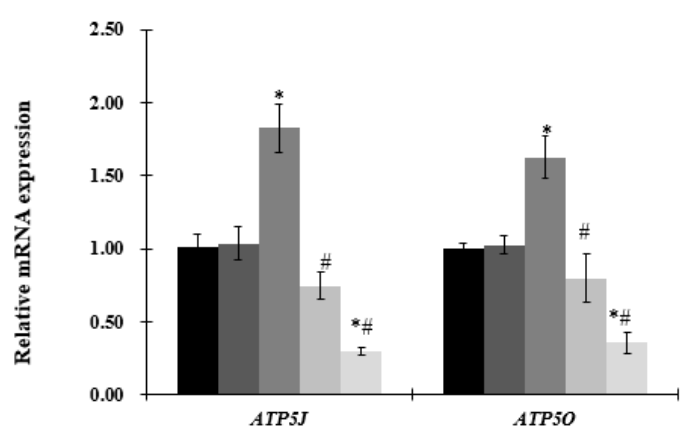

Figure 3. Effects of $\mathrm{Cr}(\mathrm{VI})$ on mitochondrial biogenesis and mitochondrial function. (A) mtDNA copy number was measured by real-time qPCR; (B) mitochondrial mass of HepG2 cells exposed to $\mathrm{Cr}$ (VI) was detected by $10-N$-nonyl acridine orange (NAO) fluorescence intensity; (C,D) mRNA expression levels of genes related to mitochondrial function were detected by real-time qPCR. Data are presented as means \pm SME of the values obtained in three independent experiments, each using triplicate cultures. After outlier analysis, the number of values used in the calculation of the corresponding mean varied from six to nine. * Compared with control, * $p<0.05$; \# compared with $2 \mu \mathrm{M}$ of $\mathrm{Cr}(\mathrm{VI})$ treatment group, $\# p<0.05$. Abbreviations: ATP synthase, $\mathrm{H}+$ transporting, mitochondrial Fo complex subunit F6, ATP5J; ATP synthase, $\mathrm{H}+$ transporting, mitochondrial F1 complex, O subunit, ATP5O; NADH: ubiquinone oxidoreductase subunit A1, NDUFA1; NADH: ubiquinone oxidoreductase subunit B1, NDUFB1; mitochondrial DNA, mtDNA.

\subsection{Upregulation of PGC-1 $\alpha$ Expression and Its Downstream Targets at Low Concentrations of $\mathrm{Cr}(\mathrm{VI})$}

Immunofluorescence, real-time qPCR and Western blot analyses were performed to investigate the expression of PGC- $1 \alpha$ and its downstream targets, which regulate mitochondrial biogenesis. There was a concentration-dependent increase in PGC- $1 \alpha$ translocation into the nucleus after exposure to up to $10 \mu \mathrm{M}$ of $\mathrm{Cr}(\mathrm{VI})$ for $24 \mathrm{~h}$. Afterwards, the response declined and became fragmented at the highest $\mathrm{Cr}(\mathrm{VI})$ concentration (Figure $4 \mathrm{~A}$ ). NRF-1 exhibited similar translocation from the cytoplasm into the nucleus, while the expression of COX II showed no changes after exposure to $\mathrm{Cr}(\mathrm{VI})$ (Figure 4A). The fluorescence of TFAM was increased and localized in the mitochondria after exposure to 5 or $10 \mu \mathrm{M}$ of $\mathrm{Cr}(\mathrm{VI})$ for $24 \mathrm{~h}$, but declined at $20 \mu \mathrm{M}$. Interestingly, exposure to $40 \mu \mathrm{M}$ of $\mathrm{Cr}(\mathrm{VI})$ caused mitochondrial filament elongation, and both mitochondria and TFAM were fragmented and localized to the nuclear perimeter (Figure 4A). The mRNA and protein expression levels of PGC- $1 \alpha$, NRF-1, and TFAM were upregulated, reaching a peak at $10 \mu \mathrm{M}$ of $\mathrm{Cr}(\mathrm{VI})$, which declined thereafter (Figure 4B,C). 


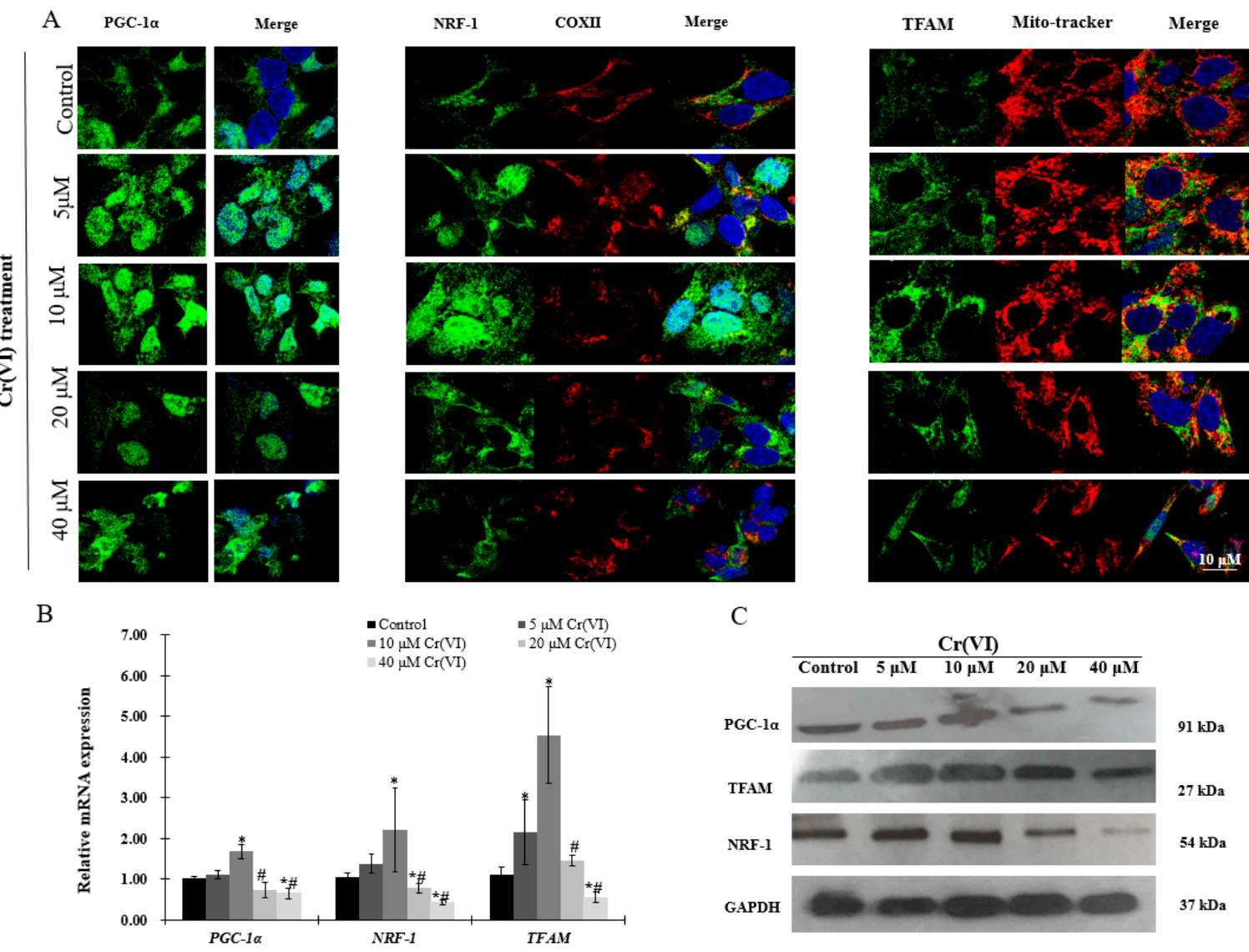

Figure 4. Effects of $\mathrm{Cr}(\mathrm{VI})$ on mitochondrial biogenesis regulatory factors in HepG2 cells. (A) PGC-1 $\alpha$ (green) expression and location of HepG2 cells exposed to $\mathrm{Cr}(\mathrm{VI})$ for $24 \mathrm{~h}$ were observed by immunocytochemistry staining; co-immunostaining of NRF-1 (green) with COX II (red); co-immunostaining of TFAM (green) with Mito-tracker (red). Nuclei were stained with Hoechst 333432. Images were obtained by confocal microscopy $(63 \times)$, scale bar: $10 \mu \mathrm{m}$; (B) mRNA expression levels of PGC- $1 \alpha$, NRF-1 and TFAM were detected by real-time qPCR; (C) protein expression levels of PGC- $1 \alpha$, NRF-1 and TFAM were examined by Western blot analysis. Data are presented as mean \pm SME of the values obtained in three independent experiments, each using triplicate cultures. After outlier analysis, the number of values used in the calculation of the corresponding mean varied from six to nine. * Compared with control, ${ }^{*} p<0.05$; \# compared with $2 \mu \mathrm{M}$ of $\mathrm{Cr}(\mathrm{VI})$ treatment group, $\# p<0.05$. Abbreviations: cytochrome c oxidase subunit 2, COX II; nuclear respiratory factor 1, NRF-1; peroxisome-proliferator-activated receptor $\gamma$ coativator- $1 \alpha$, PGC-1 $\alpha$; mitochondrial transcription factor A, TFAM; glyceraldehyde 3-phosphate dehydrogenase, GAPDH.

\subsection{Expression of Genes Involved in Mitochondrial Biogenesis Pathway after Exposure to Cr(VI) in HepG2 Cells}

To better understand the mechanism of mitochondrial biogenesis activation by low concentration of $\mathrm{Cr}(\mathrm{VI})$, genes involved in mitochondrial biogenesis pathways were analyzed by real-time qPCR. mRNA expression of FOXO1, SRIT1, AKT1 and CREB1 was similarly increased, reaching a peak at $10 \mu \mathrm{M}$ of $\mathrm{Cr}(\mathrm{VI})$, but showing a tendency to decrease thereafter (Figure 5A,B). MAPK1 and PTEN mRNA levels were decreased in a concentration-dependent manner (Figure 5A,B), without exhibiting any significant change at low concentrations of $\mathrm{Cr}(\mathrm{VI})$. 
A

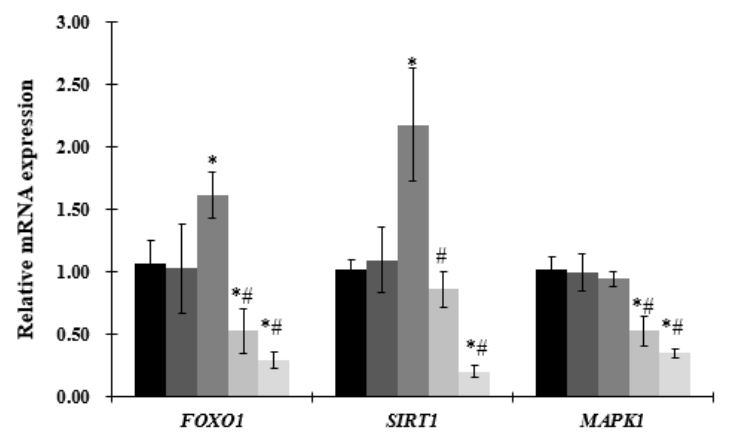

B

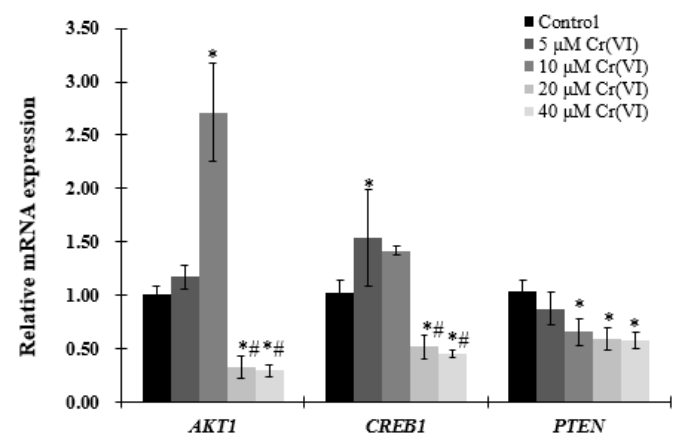

Figure 5. Effects of $\mathrm{Cr}(\mathrm{VI})$ on genes involved in regulatory pathways of mitochondrial biogenesis in HepG2 cells. mRNA expression levels were detected by real-time qPCR. (A) gene expression of FOXO1, SIRT1, and MAPK1; (B) gene expression of AKT1, CREB1, and PTEN. Data are presented as mean \pm $\mathrm{SME}$ of the values obtained in three independent experiments, each using triplicate cultures. After outlier analysis, the number of values used in the calculation of the corresponding mean varied from six to nine. * Compared with control, * $p<0.05$; \# compared with $2 \mu \mathrm{M}$ of $\mathrm{Cr}(\mathrm{VI})$ treatment group, \# $p<0.05$. Abbreviations: threonine kinase 1, AKT1; forkhead box class-O, FOXO1; mitogen-activated protein kinase 1, MAPK1; silent information regulator-1, SIRT1; phosphatase tensin homolog, PTEN.

\subsection{The Effect of $\alpha$-Tocopherol on Mitochondrial Biogenesis in HepG2 Cells Exposed to Cr(VI)}

As $\mathrm{Cr}(\mathrm{VI})$ disturbed mitochondrial biogenesis and induced redox imbalance, HepG2 cells were pretreated with antioxidant $\alpha$-tocopherol to investigate whether this component could protect mitochondrial biogenesis. After incubation with $50 \mu \mathrm{M}$ of $\alpha$-tocopherol $2 \mathrm{~h}$ before $\mathrm{Cr}(\mathrm{VI})$ exposure, cell viability was restored (Figure 6A). Furthermore, mitochondrial biogenesis, comprising recovering mtDNA copy number and mitochondrial mass, and the mitochondrial biogenesis regulators PGC-1 $\alpha$, NRF-1, NRF-2 and TFAM were maintained in a normal range (Figure 6B-E). These results indicate that $\alpha$-tocopherol can regulate mitochondrial biogenesis to resist $\mathrm{Cr}(\mathrm{VI})$ toxicity, and that mitochondrial biogenesis may be a sensitive target of $\mathrm{Cr}(\mathrm{VI})$ poisoning and detoxification.
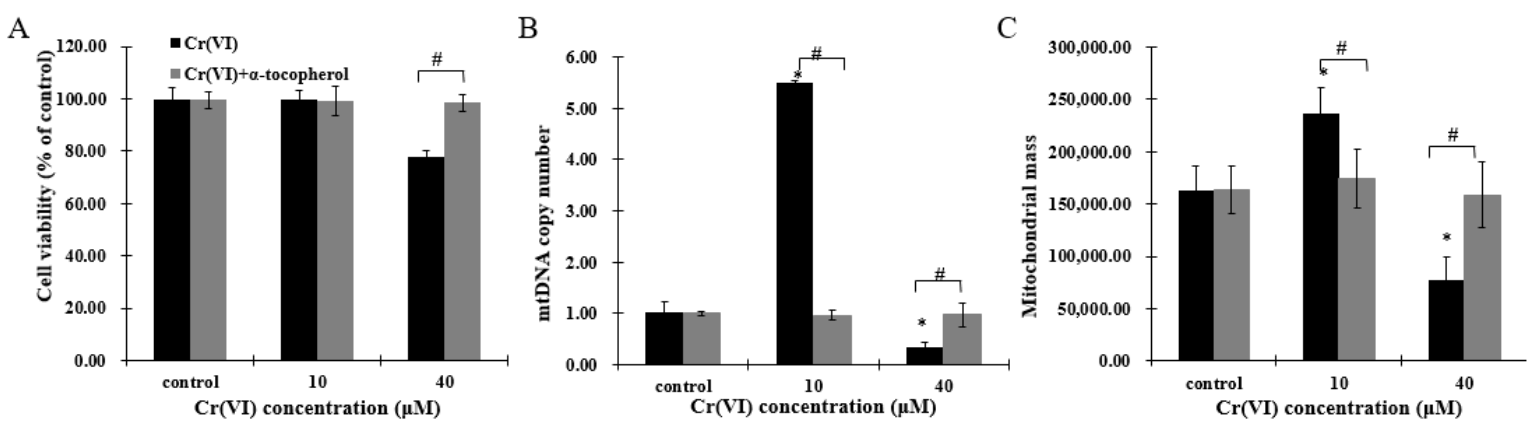

Figure 6. Cont. 
$\mathrm{D}$
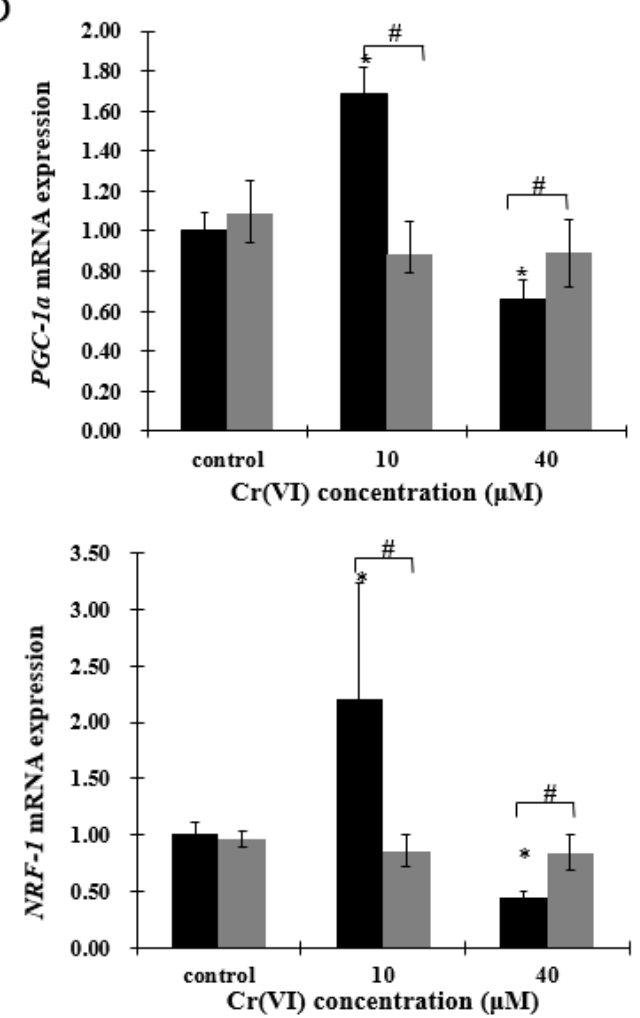
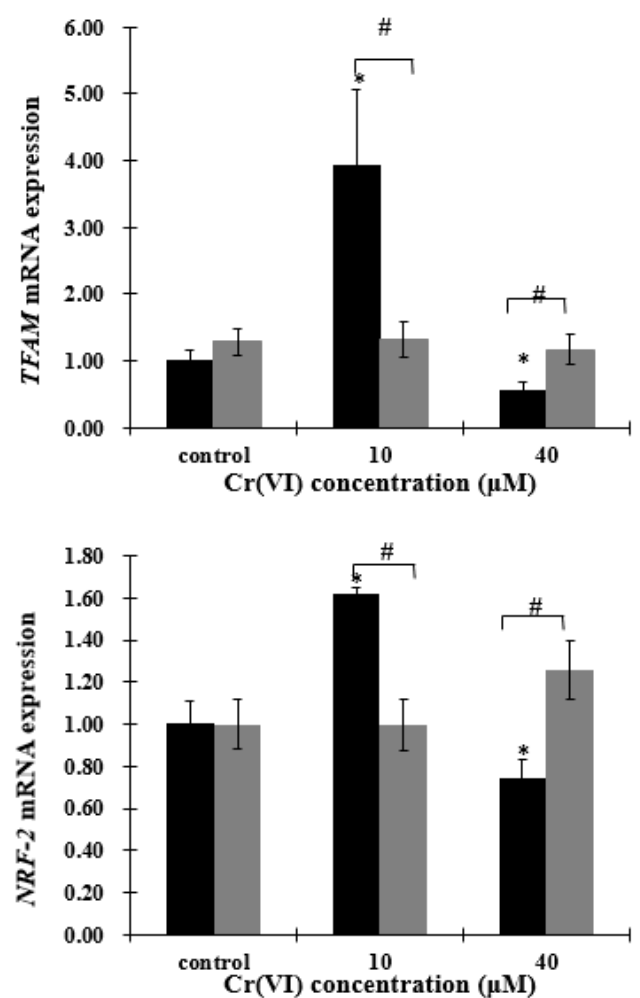

$\mathrm{E}$
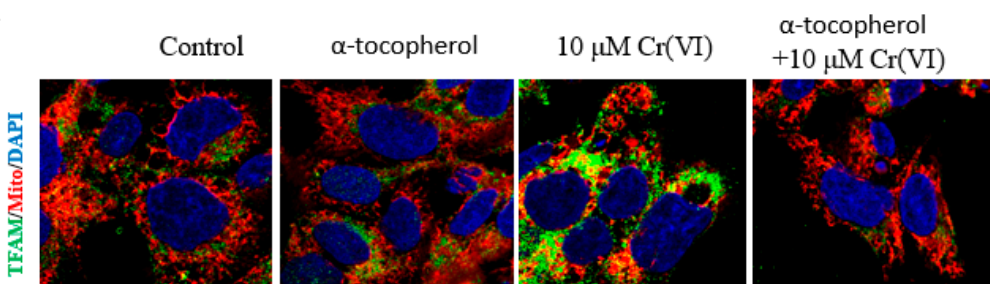

$40 \mu \mathrm{M} \mathrm{Cr}(\mathrm{VI})$

$\alpha$-tocopherol

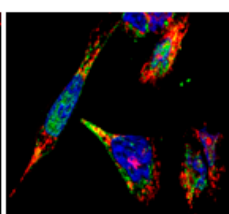
$+40 \mu \mathrm{M} \mathrm{Cr}$ (VI)
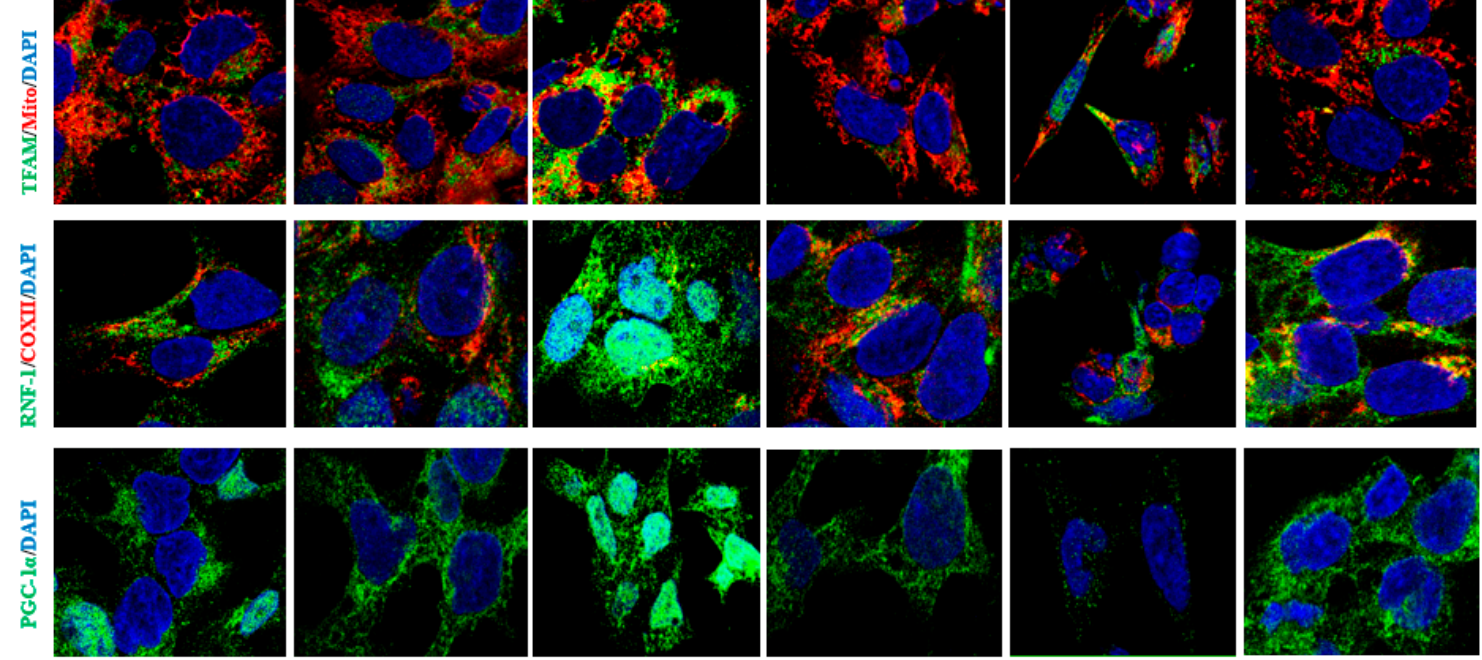

Figure 6. $\mathrm{Cr}(\mathrm{VI})$ perturbed mitochondrial biogenesis, an effect restored by $\alpha$-tocopherol in HepG2 cells. (A) Cell viability was assessed by resazurin reduction assays; (B) mtDNA copy number was measured by real-time qPCR; (C) mitochondrial mass of HepG2 cells exposed to $\mathrm{Cr}(\mathrm{VI})$ was detected by NAO fluorescence intensity; (D) gene expression related to mitochondrial biogenesis was quantified by real-time qPCR; (E) the upper panels show images of cells co-incubated with TFAM (green) and Mito-tracker (red); the middle panels show images of cells co-incubated with NRF-1 (green) and COXII (red); and the lower panels show images of PGC- $\alpha$ (green). Images were captured by confocal microscopy with a $63 \times$ objective, scale bar: $10 \mu \mathrm{m}$. Data are presented as mean $\pm \mathrm{SME}$ of the values obtained in three independent experiments, each using triplicate cultures. After outlier analysis, the number of values used in the calculation of the corresponding mean varied from six to nine. * Compared with control, ${ }^{*} p<0.05$; \# Compared with $\mathrm{Cr}(\mathrm{VI})$ treatment group, $\# p<0.05$. Abbreviations: nuclear respiratory factor 1, NRF-1; peroxisome-proliferator-activated receptor $\gamma$ coativator-1 $\alpha$, PGC- $1 \alpha$; mitochondrial transcription factor A, TFAM. 


\section{Discussion}

Presence of $\mathrm{Cr}(\mathrm{VI})$ in drinking water is a major public health concern worldwide. Drinking water contaminated with $\mathrm{Cr}(\mathrm{VI})$ causes liver injury and may increase the risk of primary liver cancer. In this study, we found that $\mathrm{LDH}$ release started at $5 \mu \mathrm{M}$ of $\mathrm{Cr}(\mathrm{VI})$ without changing cell viability until reaching concentrations up to $10 \mu \mathrm{M}$ in HepG2 cells. We speculate that LDH assay is more sensitive to detect cytotoxicity than the resazurin assay and could indicate that HepG2 cells might be able to tolerate concentrations of $\mathrm{Cr}(\mathrm{VI})$ up to a toxic threshold. Thus, we suspect the presence of a protective mechanism to help HepG2 cells survive from $\mathrm{Cr}(\mathrm{VI})$ insult.

Mitochondrial biogenesis is one of the major compensating mechanisms in response to cellular stress. In the present study, mitochondrial biogenesis, comprising mtDNA copy number and mitochondrial mass, was increased, reaching a peak at $10 \mu \mathrm{M}$ of $\mathrm{Cr}(\mathrm{VI})$. This event was also accompanied by upregulation of mRNA levels of NDUFA1 and NDUFB1, ATP5J and ATP5O, and antioxidant enzymes, including SOD1, SOD2 and GSOT1. At up to $20 \mu \mathrm{M}$ of $\mathrm{Cr}(\mathrm{VI})$, mitochondrial biogenesis tended to decrease, exhibiting a concomitant increase in the mRNA expression of inflammatory cytokines and ROS, and inhibition of the antioxidant enzymes. These results indicate that mitochondrial biogenesis was adaptively upregulated to confront cellular stress at low concentrations of $\mathrm{Cr}(\mathrm{VI})$ in HepG2 cells. Small amounts of inflammatory cytokines and ROS production, which act as a retrograde nuclear signal, can improve mitochondrial biogenesis with adaptation to the stressor. Consistently, our results showed that $\mathrm{Cr}(\mathrm{VI})$ increased TLR2/4 mRNA expression, and, subsequently, elevated ROS accumulation and TNF and $I L-1 \beta$ mRNA level in a concentration-dependent manner. Evidences have suggested that toll-like receptors (TLRs) play critical roles in the pathophysiological process of a variety of liver diseases, such as hepatitis B and hepatitis C [20]. TLR-2/4 activation leads to the production of pro-inflammatory cytokines IL-6 and TNF- $\alpha$ in hepatic NPCs and Hepatocytes [21]. Suliman et al. [22] demonstrated that, in the rat liver and heart, lipopolysaccharide stimulates mitochondrial biogenesis in response to inflammatory cell damage. They also revealed the simultaneous occurrence of mtDNA damage and compensatory mitochondrial biogenesis after exposure to Escherichia coli that resulted from the activation of TLR4 signaling pathways and nuclear factor- $\mathrm{KB}(\mathrm{NF}-\mathrm{kB})$-dependent cytokine production [22].

Slightly ROS accumulation and intense inflammation increase the transcriptional activity of NRF-1 and NRF-2 and induce expression of PGC- $1 \alpha / \beta$ to promote detoxification through direct induction of antioxidant defenses, including superoxide dismutase 2 (SOD2), catalase and glutathione peroxidase [23,24]. In the present study, low concentrations of $\mathrm{Cr}(\mathrm{VI})$ increased $P G C-1 \alpha, S O D 1$ and SOD2 mRNA level as well as NRF-2 and KEAP1 mRNA expression. Many genes encoding antioxidant enzymes are regulated by the NRF-2/KEAP1 pathway [10]. In addition, NRF-2 and its downstream factors can be activated by ROS to generate signals, resulting in co-induction of genes for mitochondrial biogenesis and countering inflammation. However, when the increasing toxicity of $\mathrm{Cr}(\mathrm{VI})$ overwhelms the cytoprotective capacity, the adverse effects could result in mitochondrial dysfunction and cell death [15]. It has been reported that mitochondrion is the sensitive target that can be perturbed by $\mathrm{Cr}(\mathrm{VI})$ [25]. Mitochondrial dysfunction is linked to oxidative stress and inflammatory response, and accumulating evidence has shown that mitochondrial dysfunction could be aggravated by increased mtROS generation, extracellular ATP and mtDNA release. This outcome was also demonstrated in the present study, as, at a high concentration of $\mathrm{Cr}(\mathrm{VI})$, mitochondrial biogenesis collapsed, accompanied by strong inhibition of NDUFA1, NDUFB1, ATP5O and ATP5J mRNA levels. Disturbance of mitochondrial function can induce cell apoptosis, and we evidenced that $\mathrm{Cr}(\mathrm{VI})$ caused apoptosis in a concentration-dependent increase. $\mathrm{Cr}(\mathrm{VI})$ induced oxidative stress and inflammatory response at low concentrations that triggered adaptively upregulated mitochondrial biogenesis and protective cell apoptosis. Nonetheless, when the adverse effects exceed the cell toxic tolerance, mitochondrial function collapses as a result of ATP depletion, and cell death switches to necrosis. This could be explained by the increased LDH release after $\mathrm{Cr}(\mathrm{VI})$ exposure, which is indicative of necrotic cell death [26]. 
PGC- $1 \alpha /$ NRF-1/2-TFAM are the most acceptable regulators involved in mitochondrial biogenesis [27]. PGC- $1 \alpha$ is the principal regulator of mitochondrial biogenesis that interacts with key nuclear transcription factors NRF-1 and NRF2, whose activation can trigger TFAM expression and then regulation of mtDNA replication and transcription [18]. In this study, both mRNA and protein levels of PGC- $1 \alpha$, NRF-1, NRF-2 and TFAM were upregulated at low concentration of Cr(VI) in HepG2 cells. In addition, we also observed that PGC- $1 \alpha$ and NRF-1 translocated to the nucleus, and TFAM became highly expressed in the mitochondria. These data suggested that a certain extent of cellular stress can activate mitochondrial biogenesis by promoting PGC-1 $\alpha, N R F-1$ and TFAM expression and translocation to protect the cell from $\mathrm{Cr}(\mathrm{VI})$ insult.

Mitochondrial biogenesis is regulated by multiple metabolic sensors, including silent information regulator-1 (SIRT1), MAPK, AKT, CREB, PTEN, among others [28]. We analyzed the potential involvement of sensors to regulate mitochondrial biogenesis, and found that low concentrations of $\mathrm{Cr}(\mathrm{VI})$ significantly elevated the mRNA levels of SIRT1, CREB1, AKT1 and FOXO1, but not the levels of $A M P K 1$ and PTEN. A number of studies have reported that silent information SIRT1 deacetylation can activate PGC-1 $\alpha$ [29] and is responsible for PTEN deacetylation. Li et al revealed that higher levels of SIRT1 was expressed in HCC specimens in comparison to normal liver tissues and cells, indicating that SIRT1 can facilitate hepatocellular carcinoma metastasis by upregulating mitochondrial biogenesis and PI3K/AKT signaling pathway [30]. PTEN can be regulated by ROS, which can also be inhibited by the enhanced ROS-dependent insulin signaling [31]. Consistent with our results, mRNA level of PTEN was decreased after exposure to $\mathrm{Cr}(\mathrm{VI})$, following the increased ROS production. PTEN can negatively regulate PI3K/AKT signaling pathway, a factor also demonstrated by the obtained data: When PTEN was decreased by $\mathrm{Cr}(\mathrm{VI})$, the mRNA level of $A K T 1$ was elevated at low concentrations of $\mathrm{Cr}(\mathrm{VI})$; but when the cells were exposed to higher concentrations, both mRNA levels of PTEN and AKT1 were downregulated, probably as a consequence of the sub-cytotoxic effect exerted by this compound. The activation of AKT induces the phosphorylation of FOXO1, leading to the exclusion of this protein from the nucleus to the cytoplasm. Tobita et al reported that inhibition of SIRT1 could impair AKT/FOXO1 pathways, causing increased gluconeogenesis in human hepatocytes [32]. Puigserver et al. showed that PGC- $1 \alpha$ interacted with and co-activated FOXO1 in hepatocytes [33]. Moreover, FOXO-PGC-1 $\alpha$ interaction is known to be involved in oxidative stress protection in vascular endothelium $[34,35]$. Activation of the CAMP-CREB pathway results in phosphorylation of CREB ( $\mathrm{p}$-CREB), which binds the CREB-response element located proximal to the PGC- $1 \alpha$ prompter, activating its transcription [36]. Consistent with the above evidence, SITR1/CREB1/ATK1 pathways might be activated to promote mitochondrial biogenesis against $\mathrm{Cr}(\mathrm{VI})$ insult. However, when mitochondrial biogenesis is collapsed by high concentration of $\mathrm{Cr}(\mathrm{VI})$, with the inhibition of protective mechanisms, the cells tended to die. In the present study, we only analyzed the mRNA levels of the factors potentially involved in mitochondrial biogenesis, but it would be interesting to investigate the deacetylation and phosphorylation levels of these factors in future studies to better understand the molecular mechanism involved in $\mathrm{Cr}(\mathrm{VI})$ cytotoxicity.

Therefore, we propose that mitochondrial biogenesis is a key adaptive mechanism to resist $\mathrm{Cr}(\mathrm{VI})$ hepatotoxicity. Addition of antioxidant supplements to the diet has been shown to maintain mitochondrial biogenesis to protect cells from death [37,38]. Previous studies reported that $\alpha$-tocopherol exerted a protective role in $\mathrm{Cr}(\mathrm{VI})$-induced oxidative damage [39-41]. Our results corroborate this finding as, at lower concentrations of $\mathrm{Cr}(\mathrm{VI}), \alpha$-tocopherol inhibited the adaptive upregulated genes, maintaining the mitochondrial biogenesis within the normal range. This indicates that pretreatment with $\alpha$-tocopherol could block the adaptive increasing mitochondrial biogenesis [42]. Truksa et al. reported that mitochondrially targeted $\alpha$-tocopherol succinate could reduce the level of mtDNA transcripts in cancer cells but not in normal tissue [43], suggesting that $\alpha$-tocopherol may depress the overexpression of mitochondrial biogenesis, which, in turn, could regulate mitochondrial homeostasis. However, $\alpha$-tocopherol restored mitochondrial biogenesis at high concentrations of $\mathrm{Cr}(\mathrm{VI})$, indicating that $\alpha$-tocopherol could protect cells from protect cells from $\mathrm{Cr}(\mathrm{VI})$-induced damage 
through modulating mitochondrial biogenesis. Pretreatment with $\alpha$-tocopherol resulted in a very strong protective role against $\mathrm{Cr}(\mathrm{VI})$-induced hepatotoxicity and it seems that the possible mechanism involved might be similar to the mechanisms of other antioxidants, such as $N$-acetylcysteine (NAC) [44]. On the one hand, $\alpha$-tocopherol effects could be attributed to extracellular reduction to prevent the cellular uptake of $\mathrm{Cr}(\mathrm{VI})$. Pretreatment of cells with $\alpha$-tocopherol might also be able to participate in the intracellular reduction of $\mathrm{Cr}(\mathrm{VI})$, which is expected to elevate the level of intercellular $\alpha$-tocopherol to increase the capacity of ROS scavenging and maintain mitochondrial homeostasis. Nevertheless, the mechanistic explanation of cellular responses to $\alpha$-tocopherol is still unclear, and needs to be fully investigated.

\section{Materials and Methods}

\subsection{Materials}

Resazurin sodium salt, potassium dichromate $\left(\mathrm{K}_{2} \mathrm{Cr}_{2} \mathrm{O}_{7}\right), \alpha$-tocopherol, and dimethyl sulfoxide (DMSO) were obtained from sigma (St. Louis, MO, USA). DMEM medium, and fetal bovine serum (FBS) were purchased from Gibco (Thermo Fisher, Waltham, MA, USA). All chemicals and solvents were analytical grade.

\subsection{Cell Culture}

Human hepatocellular carcinoma cells (HepG2) were kindly provided by Wang from the Cancer Research Center at Johns Hopkins University. HepG2 cells were maintained in DMEM medium containing $10 \%$ fetal bovine serum (FBS) and a $1 \%$ mixture of penicillin and streptomycin in a $5 \%$ $\mathrm{CO}_{2}$ humidified atmosphere at $37^{\circ} \mathrm{C}$. The medium was changed every other day, and the cells were passaged using trypsin.

\subsection{Treatment and Cytotoxicity Assay}

Cells $\left(1 \times 10^{5}\right)$ were plated in the 24-well plate with $500 \mu \mathrm{L}$ of medium, and were allowed to grow to $80 \%-90 \%$ confluence. HepG2 cells were exposed to different concentrations of $\mathrm{K}_{2} \mathrm{Cr}_{2} \mathrm{O}_{7}$ for $24 \mathrm{~h}$. $\mathrm{Cr}(\mathrm{VI})$ working solution was prepared in Dulbecco's Modified Eafle's medium (DMEM) to reach final concentrations of $0,5,10,20,40$, or $80 \mu \mathrm{M}$. Resazurin reduction assay was performed to determine cell viability after $\mathrm{Cr}(\mathrm{VI})$ treatment. Fifty microliters of resazurin $(1 \mathrm{mg} / \mathrm{mL}$ stock $)$ was added to the 24-well plates ( $500 \mu \mathrm{L} /$ well), which were incubated for $2 \mathrm{~h}$ at $37^{\circ} \mathrm{C}$. Fifty microliters of color changed medium was transferred from each well to a 96-well plate and fluorescence was measured at $530 \mathrm{~nm} / 590 \mathrm{~nm}$ (excitation/emission), using a multi-well fluorometric reader CytoFluor series 4000 (Applied Biosystems, Drive Foster, CA, USA). Lactate dehydrogenase (LDH) assay (Promega, Madison, WI, USA) was performed to determine cytotoxicity after $\mathrm{Cr}(\mathrm{VI})$ treatment. Fifty microliters of medium was transferred from each well to a 96-well plate and $50 \mu \mathrm{L}$ of substrate mix was added to each well. The 96-well plate was then incubated for $30 \mathrm{~min}$ at room temperature. Subsequently, $50 \mu \mathrm{L}$ of stop solution was added to each well and absorbance was measured at $560 \mathrm{~nm}$ using a plate reader. Data are presented as mean \pm SEM. Three independent experiments in three replicates were performed.

\subsection{Reactive Oxygen Species Measurement}

Ten thousand cells were seeded into the 96-well plate with $100 \mu \mathrm{L}$ of medium, and after reaching $80 \%$ confluence, they were treated with different concentrations of $\mathrm{Cr}(\mathrm{VI})$ for $24 \mathrm{~h}$. Cells were washed three times with serum-free medium. One hundred microliters of medium containing CellROX ${ }^{\circledR}$ Green Reagent (Thermo Fisher Scientific, Waltham, MA, USA), at final concentration of $5 \mu \mathrm{M}$, was added to each well, and incubated for $30 \mathrm{~min}$ at $37^{\circ} \mathrm{C}$. The cells were washed twice with PBS and $100 \mu \mathrm{L}$ of PBS was added to each well. The fluorescence was measured at 480/530 nm (excitation/emission) using a fluorometric reader (Applied Biosystems). 


\subsection{RNA Extraction and Quantitative Real-Time $q P C R$}

One million cells were plated in the 6-well plate with $2 \mathrm{~mL}$ of medium, and after reaching $80 \%$ confluence, they were treated with different concentrations of $\mathrm{Cr}(\mathrm{VI})$ for $24 \mathrm{~h}$. Total RNA was extracted after treatment using Trizol (Thermo Fisher Scientific). RNA quantity and purity were determined using NanoDrop 2000c (Thermo Fisher Scientific). Five hundred nanograms of RNA was reverse-transcribed using the M-MLV Promega Reverse Transcriptase (Promega, Madison, WI, USA), according to the manufacturer's instructions. The expression of genes was evaluated using TaqMan gene expression assays or SYBR Green assays. Real time qPCR was performed using a 7500 Fast Real Time system machine (Applied Biosystems). Fold changes were calculated using the 2(-Ct) method. GAPDH or $18 \mathrm{~S}$ was used as housekeeping gene for mRNA. The primer sequences were showed in Tables 1 and 2.

Table 1. Primers sequences used in SYBER Green Expression Assays.

\begin{tabular}{ccc}
\hline Gene $\mathbf{N a m e}$ & Forward Primer $\left(\mathbf{5}^{\prime} \mathbf{-} \mathbf{3}^{\prime} \mathbf{)}\right.$ & Reverse Primer $\mathbf{( 5}^{\prime} \mathbf{- 3}^{\prime} \mathbf{)}$ \\
\hline$P G C-1 a$ & TCTGTGTCACTGTGGATTGGAG & AGTTCAGGAAGATCTGGGCAA \\
Tfam & TGCGGTTTCCCTTCATCTCC & ACTAGCGAGGCACTATGGGA \\
NRF-1 & CCTGGTCCAGAACTTTACACAGA & CACTCCGTGTTCCTCCATGA \\
NRF- 2 & AACCAGTGGATCTGCCAACT & AAGTGACTGAAACGTAGCCG \\
SIRT1 & GCGGTTCCTACTGCGCGA & TCACTAGAGCTTGCATGTGAGG \\
MAPK1 & GCCGAAGCACCATTCAAGTT & GATGTCTGAGCACGTCCAGT \\
$m t D N A$ & CAAACCTACGCCAAAATCCA & GAAATGAATGAGCCTACAGA \\
AKT1 & CAGGATGTGGACCAACGTGA & AAGGTACGTTCGATGACAGT \\
CREB1 & TTCAAGCCCAGCCACAGATT & AGTTGAAATCTGAACTGTTTGGAC \\
$P T E N$ & CTCCCAGACATGACAGCCA & GCTTTGAATCCAAAAACCTTACTCA \\
Caspase3 & TGGTTTTCGGTGGGTGTG & CCACTGAGTTTTCAGTGTTCTC \\
Caspaases & AGTCTGTACCTTTCTGGCGG & TCTCCCAGGATGACCCTCTT \\
GAPDH & TGACAACAGCCTCAAGAT & GAGTCCTTCCACGATACC \\
\hline
\end{tabular}

Table 2. Primers sequences used in TaqMan ${ }^{\circledR}$ Gene Expression Assays.

\begin{tabular}{ccc}
\hline Assay Name & Assay ID & Catalog Number \\
\hline 18S & Hs99999901 & 4331182 \\
ATP5J & Hs01081394_g1 & 4331182 \\
ATP5O & Hs00919163 & 4331182 \\
NDUFA1 & Hs00915157_g1 & 4331182 \\
NDUFB1 & Hs00929425 & 4331182 \\
TLR2 & Hs02621280_s1 & 4331182 \\
TLR4 & Hs00152939_m1 & 4331182 \\
TNF & Hs01113624_g1 & 4331182 \\
IL-1 3 & Hs01555410_m1 & 4331182 \\
SOD1 & Hs00533490_m1 & 4331182 \\
SOD2 & Hs00167309_m1 & 4331182 \\
GSTO1 & Hs02383465_s1 & 4331182 \\
FOXO1 & Hs00231106_m1 & 4331182 \\
KEAP1 & hs01003430 & 4331182 \\
\hline
\end{tabular}

\subsection{Mito-Tracker Assay}

One hundred thousand cells were plated in the 24-well plate with coverslip in $500 \mu \mathrm{L}$ of medium, and after reaching $80 \%$ confluence, they were treated with different concentrations of $\mathrm{Cr}(\mathrm{VI})$ for $24 \mathrm{~h}$. Mito-tracker probe (Thermo Fisher Scientific) was added to each well at $50 \mathrm{nM}$ final concentration, then incubated for $45 \mathrm{~min}$ at $37^{\circ} \mathrm{C}$. Subsequently, the medium was removed and $500 \mu \mathrm{L}$ of fresh medium was added to each well, and incubated for another $45 \mathrm{~min}$ at $37^{\circ} \mathrm{C}$. The cells were washed twice with warm PBS and fixed in 4\% paraformaldehyde; then washed twice with PBS and blocked 
with blocking solution (10\% goat serum, $1 \%$ BSA, $0.15 \%$ saponin in PBS), and co-incubated with TFAM primary antibody.

\subsection{Measurement of Mitochondrial Mass}

Ten thousand cells were seeded into the 96-well plate with $100 \mu \mathrm{L}$ of medium, and after reaching $80 \%$ confluence, they were treated with different concentrations of $\mathrm{Cr}(\mathrm{VI})$ for $24 \mathrm{~h}$. The mitochondrial mass was examined using the fluorescent probe 10-N-nonyl acridine orange (NAO). The cells were protected from light and incubated in medium containing $5 \mu \mathrm{M}$ NAO for $30 \mathrm{~min}$ at $37^{\circ} \mathrm{C}$. NAO fluorescence intensity at $485 / 530 \mathrm{~nm}$ (excitation/emission) was determined using a microplate Reader (Gemini EM, Molecular Devices, Sunnyvale, CA, USA).

\subsection{Immunofluorescence}

One hundred thousand cells were plated in the 24-well plate with coverslip in $500 \mu \mathrm{L}$ of medium, and after reaching $80 \%$ confluence, they were treated with different concentrations of $\mathrm{Cr}(\mathrm{VI})$ for $24 \mathrm{~h}$. Cells were fixed in 4\% paraformaldehyde, washed twice in PBS and then blocked for $30 \mathrm{~min}$ in blocking solution (10\% goat serum, $1 \%$ BSA, $0.15 \%$ saponin in PBS) at room temperature. They were incubated with primary antibody PGC-1 $\alpha$ (1:50, Santa Cruz Biotechnology, Santa Cruz, CA, USA), NRF-1 (1:50, Santa Cruz Biotechnology), COXII (1:50, Santa Cruz Biotechnology) and TFAM (1:50, Santa Cruz Biotechnology) for $24 \mathrm{~h}$ at $4{ }^{\circ} \mathrm{C}$; washed 3 times with PBS, and incubated with Goat anti-Mouse $\operatorname{IgG} / \operatorname{IgM}(\mathrm{H}+\mathrm{L})$ secondary antibody, Alexa Fluor 488, 1:500, or Goat anti-Rabbit $\operatorname{IgG} / \operatorname{IgM}(\mathrm{H}+\mathrm{L})$ secondary antibody, Alexa Fluor 568, 1:500, (Thermo Fisher Scientific) for another $1 \mathrm{~h}$ at room temperature. Nuclei were stained with Hoechst for $5 \mathrm{~min}$, and mounted on slides with coverslips. Images were taken using a Zeiss UV-LSM 510 confocal microscope (Zeiss, Oberkochen, Germany).

\subsection{Caspase-3/7 Staining}

One hundred thousand cells were plated in the 24-well plate with coverslip in $500 \mu \mathrm{L}$ of medium, and after reaching $80 \%$ confluence, they were treated with different concentrations of $\mathrm{Cr}(\mathrm{VI})$ for $24 \mathrm{~h}$. Cells were washed twice with serum-free medium. Five hundred microliters of medium containing Caspase-3/7 Green Detection Regent (Thermo Fisher Scientific), at final concentration of $5 \mu \mathrm{M}$, was added to each well, and incubated for $30 \mathrm{~min}$ at $37^{\circ} \mathrm{C}$. The cells were washed twice with PBS, and $250 \mu \mathrm{L}$ of $4 \%$ paraformaldehyde was added to the wells. The cells were then incubated for $20 \mathrm{~min}$ at room temperature. Nuclei were stained with Hoechst for $5 \mathrm{~min}$, and mounted on slides with coverslips. Images were taken using a Zeiss UV-LSM 510 confocal microscope.

\subsection{Western Blot Analysis}

One million cells were plated in the 6-well plate with $2 \mathrm{~mL}$ of medium, and after reaching $80 \%$ confluence, they were treated with different concentrations of $\mathrm{Cr}(\mathrm{VI})$ for $24 \mathrm{~h}$. The cells were collected for protein extraction using lysis buffer. An equal amount of concentrated proteins was loaded on $4-15 \%$ gradient SDS-polyacrylamide gel and transferred to a polyvinylidene difluoride membrane by electroblotting at $200 \mathrm{~mA}, 4{ }^{\circ} \mathrm{C}$ for $2 \mathrm{~h}$. The membrane was blocked with $5 \%$ non-fat dry milk solution (TBS, $0.5 \%$ Tween-20, $\mathrm{pH} 7.4$ ) for $1 \mathrm{~h}$ at $4{ }^{\circ} \mathrm{C}$. The membrane was incubated with primary rabbit anti-PGC-1 $\alpha$ monoclonal antibody (Santa Cruz Biotechnology) diluted 1:500, or goat anti-rabbit TFAM (1:500, Santa Cruz Biotechnology), NRF-1 antibody (1:500, Santa Cruz Biotechnology), and anti-GAPDH primary antibody (1:2000, Cell signaling Technology, Danvers, MA, USA) in blocking solution overnight at $4{ }^{\circ} \mathrm{C}$. The membrane was washed thoroughly with TBST (50 mM Tris, $150 \mathrm{mM} \mathrm{NaCl}, 0.1 \%$ Tween 20, PH 7.4) buffer and then incubated for $1 \mathrm{~h}$ with horseradish peroxidase-conjugated anti-rabbit IgG antibody (1:3000; Santa Cruz Biotechnology) in blocking solution, detected by chemiluminescence reagent plus, and exposed to film. 


\subsection{Statistical Analysis}

Data were expressed as mean \pm standard error of the mean (SEM). Comparisons of results were calculated by SPSS 19.0 software (version 19.0, IBM, Costa Mesa, CA, USA) using one-way analysis of variance, followed by the Fisher's least significant difference (LSD) to compare the difference between subgroups. A level of $p<0.05$ was considered significantly different.

\section{Conclusions}

Overall, the antioxidase system genes and mitochondrial biogenesis were upregulated at low concentrations of $\mathrm{Cr}(\mathrm{VI})$, indicating that a compensatory mechanism might be induced to defense the $\mathrm{Cr}(\mathrm{VI})$ insult. However, if the damage overwhelms the cell protective capacity, the antioxidase system genes and mitochondrial biogenesis could be collapsed by $\mathrm{Cr}(\mathrm{VI})$. However, pretreatment of $\alpha$-tocopherol abolished excessive oxidative stress and inflammatory response, and maintained the mitochondrial biogenesis in balance, suggesting that maintenance of a homeostatic mitochondrial biogenesis level may be essential for survival of liver cells from $\mathrm{Cr}(\mathrm{VI})$ insult.

Acknowledgments: This study was supported in part by a grant from the Chinese National Natural Science Foundation (No.81172701); the Chinese Council Scholarship (201506370074); and the Graduate Student Innovation Project in the Hunan Province of China (CX2016B057). The authors would like to extend their appreciation to the estimable colleagues for helping with this study.

Author Contributions: Xiali Zhong and Caigao Zhong conceived and designed the experiments; Xiali Zhong performed the experiments; Xiali Zhong analyzed the data; Caigao Zhong contributed reagents/materials/analysis tools; Xiali Zhong and Rita de Cássia da Silveira e Sá wrote the paper.

Conflicts of Interest: The authors declare no conflict of interest.

\section{Abbreviations}

AKT1

APT5O

ATF2

ATP5J

$\mathrm{Cr}(\mathrm{VI})$

CREB

FOXO1

GSOT1

HepG2

IL-1 $\beta$

KEAP1

LDH

MAPK1

mtDNA

NDUFA1

NDUFB1

NRF

PGC- $1 \alpha$

PTEN

ROS

SIRT1

SOD

TFAM

TLRs

TNF
Threonine kinase 1

ATP synthase, $\mathrm{H}^{+}$transporting, mitochondrial $\mathrm{F} 1$ complex, $\mathrm{O}$ subunit Transcription factor ATP synthase, $\mathrm{H}^{+}$transporting, mitochondrial Fo complex subunit F6 Hexavalent chromium cAMP response element-binding protein

Forkhead box class-O

Glutathione S-transferase omega 1

Human Hepatocellular Carcinoma cells

Interleukin 1- $\beta$

Kelch like ECH associate protein 1

Lactate Dehydrogenase

Mitogen-activated protein kinase 1

Mitochondrial DNA

NADH: ubiquinone oxidoreductase subunit A1

NADH: ubiquinone oxidoreductase subunit B1

Nuclear respiratory factor

Peroxisome-proliferator-activated receptor $\gamma$ coactivator- $1 \alpha$

Phosphatase and tensin homolog

Reactive oxygen species

Silent information regulator-1

Superoxide dismutase

Mitochondrial transcription factor A

Toll-like receptors

Tumor necrosis factor 


\section{References}

1. Proctor, D.M.; Suh, M.; Mittal, L.; Hirsch, S.; Valdes Salgado, R.; Bartlett, C.; van Landingham, C.; Rohr, A.; Crump, K. Inhalation cancer risk assessment of hexavalent chromium based on updated mortality for painesville chromate production workers. J. Expo. Sci. Environ. Epidemiol. 2016, 26, 224-231. [CrossRef] [PubMed]

2. Xie, Y.; Holmgren, S.; Andrews, D.M.; Wolfe, M.S. Evaluating the impact of the US National toxicology program: A case study on hexavalent chromium. Environ. Health Perspect. 2017, 125, 181-188. [PubMed]

3. Stout, M.D.; Herbert, R.A.; Kissling, G.E.; Collins, B.J.; Travlos, G.S.; Witt, K.L.; Melnick, R.L.; Abdo, K.M.; Malarkey, D.E.; Hooth, M.J. Hexavalent chromium is carcinogenic to F344/N rats and B6C3F1 mice after chronic oral exposure. Environ. Health Perspect. 2009, 117, 716-722. [CrossRef] [PubMed]

4. Elshazly, M.O.; Morgan, A.M.; Ali, M.E.; Abdel-Mawla, E.; Abd El-Rahman, S.S. The mitigative effect of raphanus sativus oil on chromium-induced geno- and hepatotoxicity in male rats. J. Adv. Res. 2016, 7, 413-421. [CrossRef] [PubMed]

5. Bosgelmez, I.I.; Guvendik, G. N-acetyl-L-cysteine protects liver and kidney against chromium(VI)-induced oxidative stress in mice. Biol. Trace Elem. Res. 2017, 178, 44-53. [CrossRef] [PubMed]

6. Linos, A.; Petralias, A.; Christophi, C.A.; Christoforidou, E.; Kouroutou, P.; Stoltidis, M.; Veloudaki, A.; Tzala, E.; Makris, K.C.; Karagas, M.R. Oral ingestion of hexavalent chromium through drinking water and cancer mortality in an industrial area of greece-An ecological study. Environ. Health 2011, 10, 50. [CrossRef] [PubMed]

7. Beaumont, J.J.; Sedman, R.M.; Reynolds, S.D.; Sherman, C.D.; Li, L.H.; Howd, R.A.; Sandy, M.S.; Zeise, L.; Alexeeff, G.V. Cancer mortality in a chinese population exposed to hexavalent chromium in drinking water. Epidemiology 2008, 19, 12-23. [CrossRef] [PubMed]

8. Xiao, F.; Li, Y.; Luo, L.; Xie, Y.; Zeng, M.; Wang, A.; Chen, H.; Zhong, C. Role of mitochondrial electron transport chain dysfunction in $\mathrm{Cr}(\mathrm{VI})$-induced cytotoxicity in L-02 hepatocytes. Cell. Physiol. Biochem. 2014, 33, 1013-1025. [CrossRef] [PubMed]

9. Garcia-Nino, W.R.; Zazueta, C.; Tapia, E.; Pedraza-Chaverri, J. Curcumin attenuates Cr(VI)-induced ascites and changes in the activity of aconitase and $\mathrm{F}(1) \mathrm{F}(0)$ ATPase and the ATP content in rat liver mitochondria. J. Biochem. Mol. Toxicol. 2014, 28, 522-527. [CrossRef] [PubMed]

10. Piantadosi, C.A.; Suliman, H.B. Transcriptional control of mitochondrial biogenesis and its interface with inflammatory processes. Biochim. Biophys. Acta 2012, 1820, 532-541. [CrossRef] [PubMed]

11. Wenz, T. Regulation of mitochondrial biogenesis and PGC-1 $\alpha$ under cellular stress. Mitochondrion 2013, 13, 134-142. [CrossRef] [PubMed]

12. Dabrowska, A.; Venero, J.L.; Iwasawa, R.; Hankir, M.K.; Rahman, S.; Boobis, A.; Hajji, N. PGC-1 $\alpha$ controls mitochondrial biogenesis and dynamics in lead-induced neurotoxicity. Aging 2015, 7, 629-647. [CrossRef] [PubMed]

13. Fernandez-Marcos, P.J.; Auwerx, J. Regulation of PGC-1 $\alpha$, a nodal regulator of mitochondrial biogenesis. Am. J. Clin. Nutr. 2011, 93, 884s-890s. [CrossRef] [PubMed]

14. Raefsky, S.M.; Mattson, M.P. Adaptive responses of neuronal mitochondria to bioenergetic challenges: Roles in neuroplasticity and disease resistance. Free Radic. Biol. Med. 2017, 102, 203-216. [CrossRef] [PubMed]

15. Zhang, T.; Zhang, Q.; Guo, J.; Yuan, H.; Peng, H.; Cui, L.; Yin, J.; Zhang, L.; Zhao, J.; Li, J.; et al. Non-cytotoxic concentrations of acetaminophen induced mitochondrial biogenesis and antioxidant response in HepG2 cells. Environ. Toxicol. Pharmacol. 2016, 46, 71-79. [CrossRef] [PubMed]

16. Carraway, M.S.; Suliman, H.B.; Jones, W.S.; Chen, C.W.; Babiker, A.; Piantadosi, C.A. Erythropoietin activates mitochondrial biogenesis and couples red cell mass to mitochondrial mass in the heart. Circ. Res. 2010, 106, 1722-1730. [CrossRef] [PubMed]

17. Kelly, D.P.; Scarpulla, R.C. Transcriptional regulatory circuits controlling mitochondrial biogenesis and function. Genes Dev. 2004, 18, 357-368. [CrossRef] [PubMed]

18. Li, P.A.; Hou, X.; Hao, S. Mitochondrial biogenesis in neurodegeneration. J. Neurosci. Res. 2017, 95, $2025-2029$. [CrossRef] [PubMed]

19. Matsushima, Y.; Kaguni, L.S. Matrix proteases in mitochondrial DNA function. Biochim. Biophys. Acta 2012, 1819, 1080-1087. [CrossRef] [PubMed] 
20. Roh, Y.S.; Seki, E. Toll-like receptors in alcoholic liver disease, non-alcoholic steatohepatitis and carcinogenesis. J. Gastroenterol. Hepatol. 2013, 28, 38-42. [CrossRef] [PubMed]

21. Zhang, E.; Lu, M. Toll-like receptor (TLR)-mediated innate immune responses in the control of hepatitis B virus (HBV) infection. Med. Microbiol. Immunol. 2015, 204, 11-20. [CrossRef] [PubMed]

22. Suliman, H.B.; Sweeney, T.E.; Withers, C.M.; Piantadosi, C.A. Co-regulation of nuclear respiratory factor-1 by NFKB and CREB links LPS-induced inflammation to mitochondrial biogenesis. J. Cell Sci. 2010, 123, 2565-2575. [CrossRef] [PubMed]

23. Bocco, B.M.; Louzada, R.A.; Silvestre, D.H.; Santos, M.C.; Anne-Palmer, E.; Rangel, I.F.; Abdalla, S.; Ferreira, A.C.; Ribeiro, M.O.; Gereben, B.; et al. Thyroid hormone activation by type 2 deiodinase mediates exercise-induced peroxisome proliferator-activated receptor-gamma coactivator- $1 \alpha$ expression in skeletal muscle. J. Physiol. 2016, 594, 5255-5269. [CrossRef] [PubMed]

24. LeBleu, V.S.; O'Connell, J.T.; Gonzalez Herrera, K.N.; Wikman, H.; Pantel, K.; Haigis, M.C.; de Carvalho, F.M.; Damascena, A.; Domingos Chinen, L.T.; Rocha, R.M.; et al. PGC-1 $\alpha$ mediates mitochondrial biogenesis and oxidative phosphorylation in cancer cells to promote metastasis. Nat. Cell Biol. 2014, 16, 992-1015. [CrossRef] [PubMed]

25. Son, Y.O.; Hitron, J.A.; Wang, X.; Chang, Q.; Pan, J.; Zhang, Z.; Liu, J.; Wang, S.; Lee, J.C.; Shi, X. Cr(VI) induces mitochondrial-mediated and caspase-dependent apoptosis through reactive oxygen species-mediated p53 activation in JB6 Cl41 cells. Toxicol. Appl. Pharmacol. 2010, 245, 226-235. [CrossRef] [PubMed]

26. Chan, F.K.; Moriwaki, K.; de Rosa, M.J. Detection of necrosis by release of lactate dehydrogenase activity. Methods Mol. Biol. 2013, 979, 65-70. [PubMed]

27. Taherzadeh-Fard, E.; Saft, C.; Akkad, D.A.; Wieczorek, S.; Haghikia, A.; Chan, A.; Epplen, J.T.; Arning, L. PGC-1 $\alpha$ downstream transcription factors NRF-1 and TFAM are genetic modifiers of huntington disease. Mol. Neurodegener. 2011, 6, 32. [CrossRef] [PubMed]

28. Jornayvaz, F.R.; Shulman, G.I. Regulation of mitochondrial biogenesis. Essays Biochem. 2010, 47, 69-84. [CrossRef] [PubMed]

29. Yuan, Y.; Cruzat, V.F.; Newsholme, P.; Cheng, J.; Chen, Y.; Lu, Y. Regulation of SIRT1 in aging: Roles in mitochondrial function and biogenesis. Mech. Ageing Dev. 2016, 155, 10-21. [CrossRef] [PubMed]

30. Li, Y.; Xu, S.; Li, J.; Zheng, L.; Feng, M.; Wang, X.; Han, K.; Pi, H.; Li, M.; Huang, X.; et al. SIRT1 facilitates hepatocellular carcinoma metastasis by promoting PGC- $1 \alpha$-mediated mitochondrial biogenesis. Oncotarget 2016, 7, 29255-29274. [CrossRef] [PubMed]

31. Kitagishi, Y.; Matsuda, S. Redox regulation of tumor suppressor pten in cancer and aging (review). Int. J. Mol. Med. 2013, 31, 511-515. [CrossRef] [PubMed]

32. Tobita, T.; Guzman-Lepe, J.; Takeishi, K.; Nakao, T.; Wang, Y.; Meng, F.; Deng, C.X.; Collin de l’Hortet, A.; Soto-Gutierrez, A. SIRT1 disruption in human fetal hepatocytes leads to increased accumulation of glucose and lipids. PLoS ONE 2016, 11, e0149344. [CrossRef] [PubMed]

33. Puigserver, P.; Rhee, J.; Donovan, J.; Walkey, C.J.; Yoon, J.C.; Oriente, F.; Kitamura, Y.; Altomonte, J.; Dong, H.; Accili, D.; et al. Insulin-regulated hepatic gluconeogenesis through FOXO1-PGC-1 $\alpha$ interaction. Nature 2003, 423, 550-555. [CrossRef] [PubMed]

34. Olmos, Y.; Valle, I.; Borniquel, S.; Tierrez, A.; Soria, E.; Lamas, S.; Monsalve, M. Mutual dependence of FOXO3a and PGC-1 $\alpha$ in the induction of oxidative stress genes. J. Biol. Chem. 2009, 284, 14476-14484. [CrossRef] [PubMed]

35. Daitoku, H.; Sakamaki, J.; Fukamizu, A. Regulation of FOXO transcription factors by acetylation and protein-protein interactions. Biochim. Biophys. Acta 2011, 1813, 1954-1960. [CrossRef] [PubMed]

36. Liu, Z.; Liu, Y.; Gao, R.; Li, H.; Dunn, T.; Wu, P.; Smith, R.G.; Sarkar, P.S.; Fang, X. Ethanol suppresses PGC-1 $\alpha$ expression by interfering with the camp-creb pathway in neuronal cells. PLoS ONE 2014, 9, e104247. [CrossRef] [PubMed]

37. Valero, T. Mitochondrial biogenesis: Pharmacological approaches. Curr. Pharm. Des. 2014, 20, 5507-5509. [CrossRef] [PubMed]

38. Lee, W.C.; Li, L.C.; Chen, J.B.; Chang, H.W. Indoxyl sulfate-induced oxidative stress, mitochondrial dysfunction, and impaired biogenesis are partly protected by vitamin $\mathrm{C}$ and $\mathrm{N}$-acetylcysteine. Sci. World J. 2015, 2015, 620826. [CrossRef] [PubMed] 
39. Balakrishnan, R.; Satish Kumar, C.S.; Rani, M.U.; Srikanth, M.K.; Boobalan, G.; Reddy, A.G. An evaluation of the protective role of $\alpha$-tocopherol on free radical induced hepatotoxicity and nephrotoxicity due to chromium in rats. Indian J. Pharmacol. 2013, 45, 490-495. [PubMed]

40. Arreola-Mendoza, L.; Reyes, J.L.; Melendez, E.; Martin, D.; Namorado, M.C.; Sanchez, E.; Del Razo, L.M. $\alpha$-Tocopherol protects against the renal damage caused by potassium dichromate. Toxicology 2006, 218, 237-246. [PubMed]

41. Kumar, D.; Gangwar, S.P. Role of antioxidants in detoxification of $\mathrm{Cr}(\mathrm{VI})$ toxicity in laboratory rats. J. Environ. Sci. Eng. 2012, 54, 441-446. [PubMed]

42. Olguin-Martinez, M.; Hernandez-Espinosa, D.R.; Hernandez-Munoz, R. $\alpha$-Tocopherol administration blocks adaptive changes in cell NADH/NAD+ redox state and mitochondrial function leading to inhibition of gastric mucosa cell proliferation in rats. Free Radic. Biol. Med. 2013, 65, 1090-1100. [CrossRef] [PubMed]

43. Truksa, J.; Dong, L.F.; Rohlena, J.; Stursa, J.; Vondrusova, M.; Goodwin, J.; Nguyen, M.; Kluckova, K.; Rychtarcikova, Z.; Lettlova, S.; et al. Mitochondrially targeted vitamin e succinate modulates expression of mitochondrial DNA transcripts and mitochondrial biogenesis. Antioxid. Redox Signal. 2015, 22, 883-900. [CrossRef] [PubMed]

44. Luczak, M.W.; Zhitkovich, A. Role of direct reactivity with metals in chemoprotection by $N$-acetylcysteine against chromium(VI), cadmium(II), and cobalt(II). Free Radic. Biol. Med. 2013, 65, 262-269. [CrossRef] [PubMed]

(C) 2017 by the authors. Licensee MDPI, Basel, Switzerland. This article is an open access article distributed under the terms and conditions of the Creative Commons Attribution (CC BY) license (http://creativecommons.org/licenses/by/4.0/). 